POLITEIA
Politeia: Jurnal Ilmu Politik
Politeia: Jurnal Ilmu Politik, 10 (1) (2018): 52-59
ISSN 0216-9290 (Print), ISSN 2549-175X (Online)
Available online https://jurnal.usu.ac.id/index.php/politeia

\title{
Persepsi Mahasiswa Fakultas Ilmu Sosial Dan Ilmu Politik Universitas Sumatera Utara terhadap Pancasila sebagai Ideologi Negara
}

\author{
Alwi Dahlan Ritonga \& Heri Kusmanto \\ Departemen Ilmu Politik Fakultas Ilmu Sosial dan Ilmu Politik \\ Universitas Sumatera Utara, Indonesia
}

Diterima Maret 2018; Disetujui Mei 2018; Dipublikasikan Juli 2018

\begin{abstract}
Abstrak
Artikel ini adalah studi tentang persepsi Mahasiswa terhadap Pancasila sebagai ideologi negara di FISIP USU. Temuan studi ini antara lain terdapat tiga hal yang menjadi indikator dalam melihat persepsi mahasiswa terhadap Pancasila. Pertama, indikator kognisi untuk melihat tingkat pengetahuan mahasiswa terhadap Pancasila; Kedua, indikator afeksi untuk melihat perasaan mahasiswa menyangkut aspek emosional terhadap Pancasila; Ketiga, indikator evaluatif untuk melihat penilaian mahasiswa secara objektif berdasarkan kognisi dan afeksi yang mereka miliki terkait Pancasila. Metode yang digunakan adalah metode diskriptif-kuantitatif dengan teknik pengumpulan data berbentuk survei (kuesioner) dan teknik analisis data menggunakan analisis univarial dengan tabel tunggal.
\end{abstract}

Kata Kunci: Ideologi Politik; Mahasiswa, Pancasila

\begin{abstract}
This study is the study of the perception of the Students against the State ideology Pancasila at the USU EXTENSION. Focus students ' perceptions of SOCIAL about how discuss USU against Pancasila. The findings of this study, among others, there are three things that become indicators of students ' perception in seeing against Pancasila. First, the indicators of cognition to see the level of knowledge of students against Pancasila; Second, indicators of students 'feelings of affection to see concerns the emotional aspects toward Pancasila; Third, the evaluative indicators to see objectively based on student assessment of cognition and affection they have associated the Pancasila. The method used is the method diskriptif-quantitative data collection techniques with the shape of the survey (questionnaire) and data analysis techniques using univarial analysis with a single table.
\end{abstract}

Keywords: Pancasila, Student, Political Ideology.

How to cite: Ritonga, A.D. \& Kusmanto, H. (2018). Persepsi Mahasiswa Fakultas Ilmu Sosial Dan Ilmu Politik Universitas Sumatera Utara terhadap Pancasila sebagai Ideologi Negara, Politeia: Jurnal Ilmu Politik, 10 (1): 52-59.

\footnotetext{
*Corresponding author:

E-mail: alwiedahlan@gmail.com
} 


\section{PENDAHULUAN}

Penelitian ini akan mengkaji mengenai pandangan mahasiswa terhadap Pancasila sebagai salah satu elemen fundamental negara Indonesia. Sebagaimana diketahui bahwa Negara sebagai satu kesatuan organis yang terdiri dari masyarakat, wilayah dan pemerintahan sudah semestinya memiliki pandangan atau keyakinan yang dianut dalam menjalankan segala bentuk aktivitas bernegara untuk mencapai cita-cita bersama. Pandangan dan keyakinan ini kemudian disebut sebagai ideologi negara atau ideologi politik. Setiap negara yang merdeka sudah pasti memiliki ideologi tersendiri yang dianut dan implementasikan.

Sebagai suatu negara yang memiliki historitas dan dinamika yang cukup panjang tentang pergolakan dan perjuangan sampai kemudian menjadi negara yang merdeka, sudah pasti Indonesia memiliki ideologi dalam menjalankan negara. Dari penjelasan diatas dapat dipahami bahwa Ideologi memiliki kedudukan yang sangat penting dan strategis dalam menjalankan suatu negara. Sebab, dengan ideologi maka suatu negara memiliki cita-cita dan pandangan yang sama antar masyarakat yang ada dalam suatu negara tersebut.

Istilah ideologi pertama kali digunakan oleh Antoine Destutt de Tracy (1754 - 1836) pada abad ke-18, meskipun akar-akar pengertiannya dapat ditarik jauh ke belakang pada Francis Bacon (1561 - 1520), Niccolo Machiavelli (1469 - 1520), bahkan Plato (429 - 347 SM). Meskipun pembahasan tentang ideologi diduga sudah dilakukan oleh Machiavelli dan Bacon namun, karena de Tracy secara tegas menyebut ideology dan mencoba menggarapnya secara sistematis, pembahasan ideologi biasanya dimulai dengan membicarakan pemikirannya tentang ideologi. De Tracy dianggap memiliki jasa yang amat besar dalam kajian ideologi dan dianggap pelopor dalam kajian ideologi sistematis. Ia hampir selalu disinggung dalam literaturliteratur ideologi (Takwin, 2003).

Ideologi sebagai pedoman hidup bernegara dapat mempersatukan bangsa memberikan rumusan situasi negara di masa lampau, masa kini dan mengatur langkah-langkah strategis untuk mencapai kesejahteraan bangsa sebagai kesatuan yang kuat. Selain memberikan arti pada masa lampau dan masa kini, ideologi juga menunjukkan dunia baru yang akan dicapai bersama. Dengan demikian ideologi mengarahkan pikiran serta tindakan manusia kepada nilai-nilai baru yang dicita-citakannya. Ideologi merupakan penggerak atau motivator dan pemberi arah ke nila baru yang ingin diwujudkan bersama (Nurul Zuriah, 2002).

Indonesia adalah negara yang cukup unik jika dilihat dari sudut pandang ideologi. Bagaimana tidak, ketika dunia sedang dilanda wacana ideologis dan perebutan arah serta posisi ideologis Indonesia justru mengambil sikap untuk berdiri sendiri dengan sistem kepercayaan yang dimilikinya. Walaupun demikian, bukan berarti tidak ada perdebatan tentang arah dan kecenderungan ideologi yang akan dianut. Akan tetapi, pada akhirnya para founding fathers mencapai konsensus tentang satu ideologi yang tidak berada di dua blok ideologi (Liberalisme dan Sosialisme). Ideologi 
ini menjadi tata nilai dan sumber dari segala rujukan berperilaku dan bertindak baik secara individu, bermasyarakat dan bernegara. Indonesia dianggap memiliki ide-ide yang autentik serta membudaya sepanjang perjalanan sejarah nusantara sampai dengan detik-detik kemerdekaan. Berangkat dari pemikiran tersebut maka lahirlah satu konsep tentang ideologi yang seharusnya dianut oleh Indonesia. Negara Indonesia telah memiliki suatu ideologi negara bernama Pancasila. Pancasila merupakan lima dasar atau lima asas Dasar Negara Republik Indonesia.

Berangkat dari pemikiran tersebut maka lahirlah satu konsep tentang ideologi yang seharusnya dianut oleh Indonesia. Secara historis, menurut Yudi Latif dalam bukunya yang berjudul (Negara Paripurna Historitas, Rasionalitas, dan Aktualitas Pancasila) setidaknya terdapat tiga fase dalam proses terciptanya Pancasila, yaitu fase pembuahan, fase perumusan, dan fase pengesahan. Fase "pembuahan" setidaknya dimulai pada 1920-an dalam bentuk rintisan-rintisan gagasan untuk mencari sintesis antarideologi sebagai kode kebangsaan bersama (civic nationalism). Fase "perumusan" dimulai pada masa persidangan pertama BPUPK dengan Pidato Soekarno (1 Juni) sebagai cre`me de la cre`me-nya yang memunculkan istilah Panca Sila, yang digodok melalui pertemuan Chuo Sangi In dengan memebentuk "panitia sembilan" yang menyempurnakan rumusan Pancasila dari Pidato Soekarno dalam versi Piagam Jakarta (yang mengandung "tujuah kata". Fase "pengesahan" dimulai sejak 18 Agustus 1945 yang mengikat secara konstitusional dalam kehidupan bernegara (Latief, 2015). Dengan demikian kemudian dapat disimpulkan bahwa Pancasila adalah sesuatu yang lahir sebagai karya bersama.

Kajian dan penelitian ini berawal dari latar belakang adanya anggapan yang menjadikan kedudukan Pancasila dalam bermasyarakat, berbangsa dan bernegara sangat penting dan strategis. Sebagai sumber nilai dan cita-cita. Indonesia diharuskan memiliki corak ideologis yang jelas dalam menjalankan kebijakan dan arah politik nasional. Sampai pada saat ini negara masih tetap menganggap dan menjadikan Pancasila sebagai suatu nilai yang luhur dan bersifat kultuistik. Pancasila sebagai pandangan hidup harus dirawat dan dijaga eksistensinya dalam kehidupan sehari-hari baik dari aspek kemasyarakatan dan kenegaraan. Akan tetapi jika dilihat secara realistis, Pancasila hanya menjadi suatu semboyan yang bersifat sloganistik tanpa adanya bukti nyata dalam menjalankan Pancasila.

Secara konseptual, kita sering berkata bahwa Pancasila merupakan sumber nilai dari segala aspek kehidupan. Salah satu aspek yang tidak lepas dari tuntutan nilai Pancasila ialah dalam hal politik. Pancasila selalu dijadikan sebagai satu bentuk ideologi dalam berpolitik. Sehingga ada istilah ideologi politik Pancasila. Secara umum, ideologi politik Pancasila dapat dipahami sebagai bentuk dari pola kehidupan politik yang mengemban tinggi nilainilai Pancasila. Nilai-nilai Pancasila mengiringi setiap perjalanan politik baik bagi individu, sosial dan 
bernegara. Sehingga pola kehidupan yang demikian menjadi tertanam dan membudaya dalam kehidupan seharihari. Ideologi Pancasila merupakan hal yang masih penting untuk terus dijalankan dan dilestarikan di negara ini. Hal demikian juga yang dipahami oleh

Akan tetapi, ternyata ada suatu temuan yang sangat menarik yang dilakukan oleh peneliti LIPI terhadap beberapa kampus di Jawa yang menunjukkan arah yang terbalik. Ternyata, ada suatu fenomena yang menunjukkan bahwa mahasiswa menginginkan ideologi politik yang berbeda. Berdasarkan hasil penelitan tersebut menunjukkan bahwa ada mahasiswa yang ternyata telah cenderung mencari ideologi alternatif. Terlihat bahwa di dunia kampus yang sebagaimana kita ketahui terdapat orang-orang intelektual yang telah mendalami pengetahuan serta memahami secara teoritis tentang konsep suatu negara yang didapatkan berdasarkan bacaan-bacaan serta diskusi-diskusi ternyata memiliki kecenderungan ingin menggeser ideologi Pancasila ke negara Islam. Lingkungan kampus yang dihuni oleh kaum-kaum akademis saja ternyata terdapat suatu usaha untuk mempermasalahkan ideologi Pancasila. Lalu bagaimana dengan lingkungan masyarakat pada umumnya (Tempo, 2016).

Dari keterangan yang disampaikan diatas terdapat suatu fenomena yang cukup menarik. Ternyata, ada suatu fenomena yang menunjukkan bahwa mahasiswa menginginkan ideologi politik yang berbeda. Berdasarkan hasil penelitan tersebut menunjukkan bahwa ada mahasiswa yang ternyata telah cenderung mencari ideologi alternatif. Terlihat bahwa di dunia kampus yang sebagaimana kita ketahui terdapat orang-orang intelektual yang telah mendalami pengetahuan serta memahami secara teoritis tentang konsep suatu negara yang didapatkan berdasarkan bacaan-bacaan serta diskusi-diskusi ternyata memiliki kecenderungan ingin menggeser ideologi Pancasila ke negara Islam. Lingkungan kampus yang dihuni oleh kaum-kaum akademis saja ternyata terdapat suatu usaha untuk mempermasalahkan ideologi Pancasila. Lalu bagaimana dengan lingkungan masyarakat pada umumnya.

Kecenderungan yang terjadi ini merupakan suatu masalah. Hal ini melihatkan bahwa ditengah-tengah mahasiswa ternyata terdapat keraguan atau kegelisahan terhadap idoelogi Pancasila. Kasus yang termuat diatas menunjukkan bahwa mahasiswa memiliki pandangan yang berbeda dengan ideologi Pancasila. Terdapat keraguan terhadap Pancasila sehingga menimbulkan usaha untuk mencari ideologi alternatif.

Menurut peneliti hal ini sangat menarik untuk diteliti sebab ada suatu masalah ketika pemerintah di satu sisi telah berupaya ingin membumikan Pancasila akan tetapi di sisi lain terdapat upaya-upaya untuk menggeser ideologi Pancasila dan mencari alternatif ideologi Pancasila. Apakah mahasiswa masih menginginkan ideologi politik Pancasila atau tidak

Berdasarkan kasus yang terjadi diatas, peneliti merasa tertarik untuk melakukan penelitan yang mengkaji tentang persepsi mahasiswa terhadap ideologi Pancasila. Mahasiswa 
fakultas Ilmu Sosial dan Ilmu Politik merupakan mahasiswa intelektual yang aktif dan kritis yang memiliki konsentrasi keilmuan yang cocok dengan penelitian ini. Mahasiswa sebagai bagian dari elemen masyarakat yang mewakili kelompok masyarakat intelektual, yang memiliki pemahaman lebih unggul dibanding dengan masyarakat umum yang mana pandangan ataupun pendapatnya dapat menjadi tolok ukur dan menjadi pertimbangan bahkan pedoman dalam masyarakat mengenai berbagai problem yang ada, termasuk kaitannya dengan permasalahan ideologi politik pancasila. Studi ini membahas bagaimana persepsi mahasiswa FISIP USU terhadap Pancasila sebagai Ideologi Negara.

\section{METODE PENELITIAN}

Penelitian ini bersifat diskriptifkuantitatif. Pengumpulan data dengan teknik penelitian survei (kuesioner). Analisis data menggunakan analisis univariat dengan tabel tunggal. Dalam penelitian ini terdapat sebanyak 3.068 populasi dan setelah diformulasikan berdasarkan rumus Taro Yamane maka jumlah responden adalah sebanyak 99 responden dengan teknik penarikan sampel Stratified Proportional Random Sampling. Untuk mengumpulkan data maka peneliti melakukannya dengan menyebar kuesioner. Untuk menganalisis data peneliti menggunakan analisis data statistik deskriptif dengan cara menggambarkan data yang telah terkumpul sebagaimana adanya tanpa membuat kesimpulan yang berlaku untuk umum atau generalisasi.

\section{HASIL DAN PEMBAHASAN}

Analisis deskriptif pada penelitian ini diperoleh dari hasil penyebaran kuesioner kepada 99 responden mahasiswa yang ada di lingkungan Fakultas Ilmu Sosial dan Ilmu Politik Universitas Sumatera Utara. Populasi pada penelitian ini adalah mahasiswa yang sedang menjalani studi S1 dan D3 yang berjumlah 3.068. Pertanyaan atau pernyataan yang disajikan kepada responden adalah hal-hal yang berkaitan dengan persepsi baik dari segi kognisi, afeksi dan evaluasi yang ada dalam pikiran responden. Dalam penelitian ini disajikan sebanyak 18 pertanyaan penelitian dan sebanyak 3 pertanyaan yang terkait dengan karakteristik responden. Ada tiga hal yang merupakan indikator dalam melihat persepsi mahasiswa terhadap Pancasila.

\section{Komposisi} responden proporsional sesuai dengan metode dan teknik penarikan sampel dimana masing-masing jurusan telah memenuhi jumlah sampel yang dibutuhkan. Dalam penelitian ini terdapat komposisi sampel berdasarkan jurusan mulai dari yang paling besar yaitu Ilmu Komunikasi 17 responden $(17,2 \%)$ sampai dengan yang terkecil yaitu Administrasi Perpajakan 9 responden $(9,1 \%)$.

Diketahui bahwa responden yang berjenis kelamin laki-laki berjumlah 55 orang $(55,6 \%)$ dan responden yang berjenis kelamin perempuan berjumlah 44 orang $(44,4 \%)$. Dalam penelitian ini terlihat bahwa responden laki-laki lebih banyak dibanding responden perempuan.

Setiap stambuk dari jurusanjurusan yang ada di FISIP USU memiliki komposisi yang berbeda- 
beda. Terdiri dari stambuk 2013 hanya 17 orang $(17,2 \%)$, stambuk 2014 sebanyak 34 orang $(34,3 \%)$, stambuk 2015 sebanyak 25 orang $(25,3 \%)$, stambuk 2016 sebanyak $23(23,2 \%)$ dan stambuk 2016 sebanyak 23 orang $(23,2 \%)$.

Untuk mendeskripsikan hasil pengolahan data yang dilakukan oleh peneliti, maka peneliti akan menjelaskan variabel satu persatu ke dalam tabel tunggal. Di dalam tabel 1 sampai dengan 18 dikemukakan data variabel dan analisis melalui statistik deskriptif yaitu dengan cara membagi-bagi variabel berdasarkan kategori yang kemudian dianalisis melalui frekuensi dan persentase.

Pertama, orientasi kognitif adalah berbicara tentang pengetahuan. Aspek kognitif dalam penelitian ini merupakan pengetahuan yang dimiliki mahasiswa terhadap nilai-nilai yang ada dalam ideologi Pancasila. Mengetahui dan hafal setiap sila dari Pancasila, mengetahui nilai-nilai yang terkandung dalam ideologi Pancasila, dam mengetahui bahwa Pancasila sebagai ideologi negara dan memahami nilai-nilai yang terkandung di dalamnya.

Tingkat pengetahuan mahasiswa FISIP USU secara umum masih tinggi. Terlihat dari jumlah persentase ra distribusi jawaban yang menunjukkan angka rata-rata $80 \%$ memberikan jawaban Tahu dan Sangat Tahu. Mahasiswa FISIP USU masih mengetahui bahwa Pancasila merupakan Ideologi politik negara Indonesia. Serta mengetahui kandungan nilai yang terdapat di dalam Pancasila.

Dari data tersebut maka dapat dilihat bahwa hampir seluruh mahasiswa FISIP USU memiliki pengetahuan yang tinggi terhadap Pancasila. Angka persentase tersebut merupakan angka yang cukup tinggi jika dijadikan sebagai ukuran untuk melihat tingkat pengetahuan mahasiswa terhadap Pancasila.

Kedua, orientasi afektif adalah berbeda dengan orientasi kognitif, oleh sebab orientasi afektif ini bergerak di dalam konteks perasaan. Perasaan-perasaan seperti diperhatikan, diuntungkan, merasa adil, sejahtera, suka atau tidak suka, ataupun sejenisnya, kerap lebih menentukan ketimbang faktor pengetahuan.

Orientasi afektif disini merupakan perasaan yang menyangkut aspek emosional subjektif dari mahasiswa terhadap objek pandangan yaitu Pancasila. Adapun yang menjadi indikator dalam melihat orientasi ini yaitu; 1) Fungsi Etis, yaitu sebagai panduan dan sikap serta perilaku kelompok masyarakat dalam kehidupan kenegaraan dan kebangsaan. 2) Fungsi Integrasi, yaitu nilai yang menjadi pengikat suatu bangsa atau masyarakat; 3) Fungsi Kritis, yaitu sebagai ukuran nilai yang dapat digunakan untuk melakukan kritik terhadap nilai atau keadaan tertentu; 4) Fungsi Praxis, yaitu sebagai acuan dalam memecahkan masalah-masalah kongkrit; 5) Fungsi Justifikasi, yaitu ideologi sebagai nilai pembenaran atas suatu tindakan atau kebijakan tertentu yang dikeluarkan oleh suatu kelompok tertentu.

Berdasakan hasil penelitian yang telah dilakukan oleh peneliti di lapangan, peneliti menemukan fakta bahwa secara emosional mahasiswa FISIP USU merasa bahwa Pancasila 
memiliki dampak dalan kehidupan sehari-hari secara pribadi maupun dalam bernegara. Terbukti bahwa persentase distribusi jawaban responden berapada pada kisaran $72 \%$ menjawab masih positif (Setuju, Sangat Setuju).

Secara emosional mahasiswa FISIP USU masih menganggap bahwa Pancasila merupakan sesuatu yang melekat dalam kehidupan individu mereka. Terbukti bahwa sebagian besar mahasiswa menganggap bahwa Pancasila masih menjadi panduan dalam bersikap dan berperilaku sehari-hari. Walaupun ternyata ada juga yang menganggap netral atau tidak menyatakan sikap dan bahkan tidak setuju. Pancasila juga masih menjadi pandangan hidup bagi mahasiswa FISIP USU. Berdasarkan data, dominasi masih terletak pada persepsi yang positif terhadap Pancasila. Setiap pernyataan yang diajukan oleh peneliti selalu di dominasi oleh jawaban yang positif. Akan tetapi walaupun demikian, tidak dapat dipungkiri bahwa ada sebagian kecil mahasiswa yang merasa bahwa Pancasila tidak sesuai secara emosional dengan dirinya. Menurut peneliti hal ini tidak terlepas dari adanya ketidak sesuaian antara cita-cita dengan kenyataan di lapangan. Pemerintah tidak berhasil memberikan contoh yang sesuai dengan harapan Pancasila.

Ketiga, orientasi Evaluatif merupakan campuran antara orientasi kognitif dan afektif di dalam bentuk keputusan/tindakan. Orientasi Evalutif muncul akibat adanya pengaruh dari orientasi kognitif dan afektif. Indikator evaluatif berisi tendensi atau kecenderungan untuk bertindak atau bereaksi terhadap suatu objek yang dipersepsi secara tertentu. Aspek evaluatif menunjukkan bagaimana tanggapan mahasiswa terhadap objek yaitu Ideologi Pancasila yang diwujudkan dengan tindakan yang dapat berupa kritikan terhadap hasil yang tidak sesuai dengan Pancasila.

Untuk melihat orientasi ini maka peneliti menggunakan indikator dibawah ini di setiap pertanyaan penelitian: 1) Konsistensi mahasiswa terhadap ideologi Pancasila; 2) Pandangan terhadap upaya mengganti ideologi Pancasila; 3) Relevansi Ideologi Pancasila

Berdasarkan penelitian yang dilakukan di lapangan maka ditemukan bahwa mahasiswa FISIP USU masih menginginkan Pancasila sebagai ideologi negara Indonesia. Pendapat ini dapat disimpulkan berdasarkan hasil data secara statistik yang menunjukkan angka 63\% Setuju dan Sangat Setuju jika Pancasila masih diperlukan eksistensinya. Walaupun terdapat sebanyak 8\% mahasiswa yang memiliki persepsi yang berbeda dengan menganggap bahwa Pancasila secara negatif. Hal ini mengindikasikan bahwa ada sebagian kecil mahasiswa yang memiliki pandangan bahwa Pancasila sudah seharusnya digantikan dengan ideologi lain.

\section{SIMPULAN}

Dengan demikian, maka dalam penelitian ini ditemukan fakta bahwa ternyata mahasiswa di Fakultas Ilmu Sosial dan Ilmu Politik Universitas Sumatera Utara memiliki tiga persepsi dalam melihat Pancasila sebagai Ideologi Negara. Ketiga persepsi tersebut menunjukkan bahwa: pertama, Secara Kognisi Mahasiswa 
FISIP USU memiliki pengetahuan yang tinggi; Kedua, secara afektif mahasiswa FISIP USU merasa Pancasila merupakan sesuatu yang melekat dalam hidup mereka; Ketiga, secara umum mahasiswa FISIP USU masih menilai secara positif terhadap Pancasila dan menginginkan agar Pancasila tetap eksis.

\section{DAFTAR PUSTAKA}

Abdullah, H.R, (2005). Pelaksanaan Otonomi luas dengan pemilihan kepala daerah secara langsung, Jakarta: Raja Gravido persada.

Ahmad, A. (2005). Pilkada Langsung dan Masa Depan Demokrasi, Averroes Press.

Ahmadi, A. (1979). Psikologi Sosial. Surabaya: PT Bina Ilmu.

Aminah, S. (2014). Kuasa Negara pada ranah politik local, Jakarta: Predana Media Grup.

Asfar, M. (2006). Pemilu dan Perilaku Memilih 1955-2004. Pustaka Eureka.

Budiardjo, M. (2008). Dasar-Dasar Ilmu Politik Edisi Revisi. Jakarta : Gramedia.

Firmanzah. (2007). Marketing Politik. Jakarta: Yayasan Obor Indonesia..

Horald, F.G.. (1934). Ensyklopedia Of The Social Science. New York : Mc Grew Hill Book Company.

https://nasional.tempo.co/read/news/2 016/02/25/173748047/peneliti-lipiada-upaya-menggeser-ideologidari-pancasila. Diakses pada Tanggal 25 Februari 2016.

https://nasional.tempo.co/read/news/2 016/02/25/173748047/peneliti-lipiada-upaya-menggeser-ideologidari-pancasila. Diakses pada Tanggal 25 Februari 2016

Latif, Y. (2015). Negara Paripurna Historitas, Rasionalitas, dan
Aktualitas Pancasila. Jakarta: PT. Gramedia Pustaka Utama.

Latif, Y. (2015). Negara Paripurna Historitas, Rasionalitas, dan Aktualitas Pancasila. Jakarta: PT. Gramedia Pustaka Utama.

Marijan, K. (2010). Sistem Politik Indonesia: Konsolidasi Demokrasi Pascaorde Baru. Jakarta: Kencana Prenada Media Grup.

Martono, N. (2010). Metode Penelitian Kuantitatif, Analisis Data Sekunder, Jakarta: Rajawali Press.

Prihatmoko, J.J. (2005). Pemilihan Kepala Daerah Langsung : Filosofi, sistem dan problema penerapan di Indonesia. Yogyakarta: Pustaka

Rahardjo \& Dawam, M,. (1996). Intelektual Inteligensia Dan Perilaku Politik Bangsa. Bandung: Mizan.

Runua, N. (1994). Dinamika Politik Indonesia. Dari Pemilu 1992 Sampai Kabinet Pembangunan VI. Jakarta: Bima Rena Pariwara.

Siagian, M. (2011). Metode Penelitian Sosial (Pedoman Praktek Penelitian Bidan Ilmu-ilmu Sosial dan Kesehatan). Medan: PT Grasindo Monoratama.

Singarimbun, M. (2006). Metode Penelitian Survei. Jakarta: LP3ES.

Takwin, B. (2003). Akar-akar Ideologi: Pengantar Kajian Konsep Ideologi dari Plato hingga Bourdieu. Yogyakarta; Jalasutra.

Takwin, B. (2003). Akar-akar Ideologi: Pengantar Kajian Konsep Ideologi dari Plato hingga Bourdieu. Yogyakarta; Jalasutra.

Thubany, S.H. (2005). Pilkada BIMA 2005: Era Baru Demokratisasi Lokal Indonesia. Yogyakarta: Gramedia Pustaka.

Zuriah, N. (2002). Revitalisasi Radikalisasi Filsafat Dan Ideologi Pancasila Di Era Reformasi Globalisasi. Malang:

Zuriah, N. (2002). Revitalisasi - Radikalisasi Filsafat Dan Ideologi Pancasila Di Era Reformasi - Globalisasi. Malang. 